\title{
A Castração E SEUS DESTINOS NA CONSTRUÇÃO DA PATERNIDADE
}

\author{
Jacqueline de Oliveira Moreira* \\ Adriana Araújo Pereira Borges**
}

\section{Resumo}

Freud elaborou três versões sobre o pai: Édipo, o Pai da Horda e Moisés. Nessas versões o autor relata o parricídio e, portanto, para Freud, o pai é o pai morto. Se o filho é uma das soluções para a mulher, para o homem o filho assume os contornos do objeto fóbico, pois o pai se relaciona de forma privilegiada com a castração. $\mathrm{O}$ acesso à paternidade exige que o homem reatualize seu Édipo, colocando novamente seu desejo à prova e reativando conflitos adormecidos. Tal percurso leva, inevitavelmente, ao encontro com a castração que produz perdas narcísicas. No entanto, aqueles homens que suportam o primeiro impacto e sustentam o lugar de pai transmitem aos filhos muito mais do que genes.

Palavras-chave: Complexo de Édipo; castração; paternidade.

\section{Abstract}

THE CASTRATION AND ITS FUTURE IN PATERNITY CONSTRUCTION

Freud developed three versions about the figure of the father: Oedipus, Father of the Horde, and Moses. In these versions the author reports the parricide. If the son is one of the solutions for the woman, for the man the son assumes the profile of a phobic object, because there is a privileged relationship between father and castration. The access to paternity claims that the man modernizes his Oedipus. This way takes, inevitably, to the encounter of the castration, which results in narcissistic lost. However, those men that support the first impact and sustain the father's position pass to their kids more than genes.

Keywords: paternity; castration; Oedipus.

* Doutora em Psicologia Clinica - PUC/SP, Mestre em Filosofia - UFMG, Professora Adjunta III da PUC/MG, Professora do Mestrado da PUC/MG, Psicóloga Clínica.

** Mestre em Psicologia pela PUC/MG, Professora do Instituto Superior de Educação Anísio Teixeira e da Fundação Helena Antipoff. 
No início deste século, presenciamos uma discussão sobre um suposto declínio da figura do pai na sociedade contemporânea. Alguns teóricos, no campo das ciências humanas, tentam pensar esse tema. Amazonas e Braga (2004), por exemplo, após apresentarem a concepção de diferentes autores sobre o conceito de função paterna, questionam sobre a presença dessa função nas atuais configurações familiares. As autoras concluem que a discussão mais importante não é sobre a presença de um pai, quer seja ele biológico ou não, mas, sim, do Outro, que tanto pode estar ancorado no pai quanto nos irmãos, avô, avó ou quem quer que seja (Amazonas \& Braga, 2004).

Essa polêmica sobre um suposto declínio da função paterna nos convida a buscar elementos que apresentem as especificidades da experiência edípica para o menino, ou seja, o futuro candidato a pai. O fato que nos conduz é a constatação clínica do conflito masculino diante da possibilidade da paternidade. Parece que, no mundo contemporâneo, os homens desenvolveram uma fobia frente à paternidade. Por que o medo da paternidade? Essa é a questão que guia este texto. Buscaremos na teoria freudiana, mais precisamente na reflexão sobre o Édipo e a Castração, pistas compreensivas desse medo.

O complexo de Édipo constitui uma das problemáticas fundamentais da teoria e da clínica psicanalítica. Para a teoria psicanalítica de Freud, o momento crucial da constituição do sujeito situa-se no campo da cena edípica. Dessa forma, o Édipo não é somente o complexo nuclear das neuroses, mas, também, o ponto decisivo da sexualidade humana, ou melhor, do processo de produção da sexuação. Será a partir do Édipo que o sujeito irá estruturar e organizar o seu vir-a-ser, ou acontecer psíquico, sobretudo em torno da diferenciação entre os sexos e de seu posicionamento frente à angústia de castração. Freud irá remeter-se, em sua teorização sobre o Édipo, a autores e personagens clássicos da literatura mundial. Obras como Hamlet de Shakespeare e a trama do parricídio dos Irmãos Karamazov reencenaram o mito de Édipo da tragédia de Sófocles.

A hipótese da importância da cena edípica na trama da subjetividade aparece cedo na teoria freudiana. Em 1897, Freud lança a ideia do Édipo numa carta para Fliess. Entretanto, só tardiamente, após a formulação da Pulsão de Morte e de sua articulação com o conceito de castração, é que a ideia ganhará uma dimensão de conceito fundador. Contudo, Freud dedica apenas um texto específico ao complexo de Édipo, a saber: "A dissolução do Complexo de Édipo" (Freud, [1924] 1976). Segundo Moreira (2002), em um primeiro momento o Édipo aparece associado à teoria dos sonhos. Em seguida, ganha um estatuto de complexo estruturante da cultura através do mito de “Totem e tabu”. A próxima discussão sobre o Édipo gira em torno do problema da identificação. Só após 1920 o Édipo aparece organizado em torno do conceito de castração. 
Encontramos cinco textos que expressam a problemática do quarto movimento da teorização freudiana, ou seja, que anunciam a castração como o centro do Édipo: "A organização genital infantil: uma interpolação na teoria da sexualidade" ([1923] 1976); "A dissolução do Complexo de Édipo" ([1924] 1976); "Algumas consequências psíquicas da distinção anatômica entre os sexos" ([1925b] 1976); "Sexualidade feminina" ([1931] 1976) e "Feminilidade" (Conferência XXXIII) ([1933] 1976). Nos três primeiros, encontramos uma reflexão sobre as consequências da diferença entre o Édipo na menina e no menino; a consideração da angústia de castração como ponto nodal de sua resolução; e a ideia do falo como o objeto do desejo. Nos últimos, presenciamos uma maior preocupação com a constituição da feminilidade a partir das diferenças e peculiaridades do conflito edípico na menina.

O quarto movimento de teorização sobre o Édipo parece centrar a discussão sobre a lei da castração. Freud afirma, em "A organização genital infantil”, que a angústia de castração recai sobre o falo: "o significado do complexo de castração só pode ser correntemente apreciado se sua origem na fase da primazia fálica for também levada em consideração" (Freud, [1923] 1976: 182).

O falo é o único significante da sexualidade, por isso a teorização psicanalítica considera apenas a existência da masculinidade. A feminilidade é apresentada como um enigma que aparece na puberdade. Diante dessa ausência de significante, a menina vivenciará um destino diferente na trama edipiana. A angústia de castração que promove o declínio do Édipo no menino representa, na menina, a sua possibilidade de entrada no drama edípico. "Enquanto, nos meninos, o complexo de Édipo é destruído pelo complexo de castração, nas meninas ele se faz possível e é introduzido através do complexo de castração" (Freud, [1925b] 1976: 318).

Parece-nos que essa confusão em torno da feminilidade está assentada no engodo imaginário que iguala pênis a falo. No momento em que Freud utiliza o significante falo para designar o objeto do desejo (Freud, [1923] 1976), ele realiza um descolamento da biologia. Entretanto, a equação pênis igual a filho parece reproduzir o engodo (Freud, [1924] 1976), pois seria melhor anunciar falo igual a filho. Não estamos questionando o conteúdo da ideia, mas a forma como é inscrita abre a possibilidade para a crença imaginária do pênis como "o objeto". Crença comum, vulgarmente empírica e que, portanto, é incapaz de apreender o estatuto simbólico daquela equação.

Entendemos, não obstante, que as psicopatologias podem se fundamentar nessa confusão entre pênis e falo. Cabe à teoria desvelar e denunciar o equívoco de tal identificação e explicar as suas razôes. Assim, haveria a possibilidade de se assentar a masculinidade na imaginarização concretizante que iguala falo a pênis, produzindo vários outros enganos na discussão sobre gênero. 
O que nos interessa nesta discussão é a relação do menino com a castração e os possíveis efeitos dessa relação com a possibilidade da paternidade. Para Freud, a mulher não tem angústia de castração, mas, sim, uma castração realizada.

[...] a diferença entre o desenvolvimento sexual dos indivíduos dos sexos masculino e feminino no estádio que estivemos considerando é uma consequência inteligível da distinção anatômica entre seus órgãos genitais e da situação psíquica aí envolvida; corresponde à diferença entre uma castração que foi executada $\mathrm{e}$ outra que simplesmente foi ameaçada (Freud, [1925b] 1976: 319).

Acreditamos que essa afirmação se assenta em uma confusão entre os registros imaginário e simbólico. Podemos pensar na menina como uma castração realizada, se nos prendermos a um registro de imagens. Mas a castração se refere ao falo e não ao pênis, portanto se vincula a uma verdade simbólica.

Vamos fazer um exercício de pensamento e conceder um crédito a essa ideia da maior aceitação da castração na menina. Podemos levantar a hipótese de que é esse reconhecimento da castração que viabiliza a maternidade. Na célebre equação filho igual a pênis, a menina busca na maternidade uma saída para sua condição de castrada. No caso do menino, a saída do Édipo acontece a partir da ameaça de castração. Assim, considerando, aqui, a tese freudiana de que o menino declina do Édipo frente à ameaça de castração, não seria a paternidade um encontro do menino com a castração que se encontrava apenas na forma de ameaça?

Portanto, não podemos falar do mesmo reconhecimento da castração entre meninos e meninas. As meninas se deparam com a castração no real do corpo. Verdade que possibilita, segundo a teoria freudiana, a entrada no Édipo. E os meninos, por sua vez, se encontram com a angústia de castração que viabiliza o declínio do Édipo. Ou seja, a castração para o menino é uma ameaça que pode ser driblada. Mas em que momento da trama existencial o menino poderá se encontrar com essa verdade para além do campo da ameaça?

Faz-se necessário ressaltar o duplo movimento da castração. Segundo Laplanche (1988), a castração é, ao mesmo tempo, castigo e promessa. Castigo para punir a transgressão da lei; e promessa de realização humana, porque só ela possibilita a passagem da ordem imaginária para a ordem simbólica.

Rocha (2002) percebe que a dialética castigo/promessa aparece, no texto freudiano, de forma diferente para meninas e meninos. A ideia de que a menina sofreu uma desilusão fálica com a mãe, e que este fator possibilitou a mudança de zona erógena e de objeto sexual, coloca a menina na relação com o pai. Esta relação aparece como uma promessa de receber deste um falo. A menina não é castigada por desejar a mãe, mesmo porque, na teoria freudiana, essa relação está fora do 
complexo de Édipo. É como se a menina, no ato de nascer menina, já estivesse castigada; qualquer novo acontecimento é uma promessa.

No caso do menino, o pêndulo pesa mais para o lado do castigo. A castração aparece para o menino como um castigo por ter desejado a mãe. A promessa entra em cena, secundariamente, como possibilidade de desejar. Calligaris (1996), refletindo sobre a função do pai enquanto interdito, revela: "O que me é proibido, os limites que me são impostos como criança, é justamente o que me outorga e me permite reconhecer o meu lugar, o lugar de filho" (Calligaris, 1996: 43) E podemos acrescentar que este interdito instaura a possibilidade do desejo, porque a condição do desejo é a falta.

O interessante é que o texto freudiano abre espaço para pensar que a castração como promessa não tem o mesmo peso para meninas e meninos. E, por sua vez, a castração como castigo não opera da mesma forma com meninos e meninas. A hipótese é a seguinte: a castração como promessa é a condição da maternidade. Sendo assim, a paternidade ficaria no campo mais espinhoso.

É importante frisar que existe um ponto em comum entre meninas e meninos no que se refere às duas vertentes da castração. A castração como castigo aparece para os dois pelo movimento de buscar o todo. Já a castração como promessa surge a partir da instauração do sujeito de desejo, aquele que se organiza em torno da falta. Todavia, no ponto que se refere à filiação, o filho representa para a menina a promessa que opera pela lógica fálica. Mas, para o menino, talvez, seria o filho exatamente a efetivação da castração.

Acreditamos que, talvez, a paternidade seja esse momento. Um elemento que corrobora essa hipótese é a constatação de que os três mitos freudianos sobre o pai possuem um ponto em comum: a ideia da morte do pai. Os três momentos paradigmáticos da reflexão sobre o pai são: o mito de Édipo, "Totem e tabu" e "Moisés e o monoteísmo".

O mito do Édipo aparece, na teoria freudiana, como fundante do sujeito do inconsciente e da cultura. As reflexões sobre o Édipo remontam Freud à tragédia grega de Sófocles. A primeira menção à problemática edípica ocorre no Rascunho $\mathrm{N}$ que segue a Carta 64, datada de 31 de maio de 1897 (Freud, [1950] 1976: 350). Freud inicia a carta a Fliess anunciando um pressentimento de que em breve descobrirá a origem da moralidade. Segue apresentando um sonho, que se refere a sentimentos "supercarinhosos" para com sua filha mais velha, Mathilde. Não seria um sonho edípico? Sentimentos supercarinhosos não poderiam anunciar um sonho erótico ou até mesmo incestuoso? Freud continua na sua descrição do sonho: "Hella era o nome da filha no sonho" (Freud, [1950] 1976: 350); num processo de associação, Freud desliza do significante Hella para a mitologia da 
antiga Hélade e lembra o entusiasmo da filha para com os heróis helenos. Finaliza a interpretação do sonho com a seguinte frase: "O sonho, é claro, mostra a realização do meu desejo de encontrar um pai que seja o causador da neurose e, desse modo, pôr fim às dúvidas que ainda persistem em mim sobre esse assunto" (Freud, [1950] 1976: 350).

Na carta 71 (Freud, [1950] 1976), encontramos a primeira referência direta ao mito transposto por Sófocles como "Oedipus Rex". É interessante que Freud inicia a carta relatando seu sonho com a empregada desaparecida. Esse relato remete-nos à "Interpretação dos sonhos", na passagem sobre Representação por símbolos nos sonhos - outros sonhos típicos (Seção E do Capítulo VI), em que aparece uma extensa nota de rodapé com vários acréscimos em 1911, 1914 e 1925 e que contém um comentário sobre a questão dos sonhos edípicos disfarçados. Não seria o sonho com a babá um modelo de deslocamento para disfarçar o desejo pela mãe?

Parece haver um fio associativo entre o sonho que abre a carta e a afirmação freudiana da existência de um único pensamento genérico, a saber: a verificação universal, também na própria história de Freud, da paixão pela mãe e do ciúme em relação ao pai na infância E é exatamente nesse ponto que aparece, pela primeira vez, a referência ao "Oedipus Rex".

$\mathrm{Na}$ sequência, Freud aventa a hipótese de que a experiência psicológica de Hamlet é similar à tragédia grega. Finaliza interpretando o tormento de Hamlet: "a sua consciência moral exacerbada é resultante de um sentimento de culpa inconsciente, pois ele - Hamlet - desejou e/ou fantasiou o mesmo destino para o pai” (Freud, [1950] 1976: 350). Portanto, encontramos nessa passagem uma vinculação entre a origem da moralidade e a problemática edípica, retomando o primeiro parágrafo da Carta 64.

Desta forma, Freud constrói, progressivamente, a ideia do Édipo como um mito universal e fundante do sujeito do inconsciente. É digno de nota que, no mito grego, Laio é morto por Édipo. Mas é interessante pensar que, antes de Édipo nascer, Laio se sentia ameaçado pelo filho que viria e tenta se livrar dele.

Já o texto de "Totem e tabu" (Freud, [1913] 1976) introduz a discussão sobre as origens da civilização a partir de estudos antropológicos. Freud constrói a figura de um pai tirano, detentor de todas as mulheres da tribo. Um macho mais velho e mais forte, com plenos poderes e poucos deveres. Revoltados, os filhos matam o pai e o devoram, realizando um banquete totêmico, cujo resultado é a identificação ao pai morto.

Dividido em quatro ensaios, "Totem e tabu" faz uma aproximação entre neurose, povos primitivos e infância. $\mathrm{O}$ tabu do incesto é o elo que liga esses três 
termos. No primeiro ensaio desta obra, intitulado O horror ao incesto, Freud questiona como tribos afastadas e selvagens, como os aborígines da Austrália, criaram leis tão rígidas para proibir as relaçôes incestuosas. Estas eram proibidas através dos totens, representados, na maioria das vezes, por um animal. Estes totens nomeavam os clãs pertencentes à tribo e estabeleciam, assim, regras contra relações sexuais entre pessoas pertencentes ao mesmo totem.

Tabu e ambivalência emocional é o nome do segundo ensaio, em que Freud resgata o sentido da palavra tabu. Em Animismo, magia e onipotência de pensamentos, o que está em questão é o pensamento mágico do homem primitivo. $\mathrm{O}$ quarto ensaio, intitulado $\mathrm{O}$ retorno do totemismo na infância, associa o mito da horda ao totemismo e ao complexo de Édipo através das consideraçōes tecidas acerca do caso Hans. Hans, aos cinco anos de idade, começa a apresentar uma fobia a cavalos. Na época, isso causava um grande transtorno, pois cavalos e carroças eram o meio de transporte mais utilizado. Sua fobia, portanto, por vezes o impedia de sair à rua. Analisando os sintomas de Hans e suas construçôes acerca dos mesmos, Freud percebe que, na verdade, o cavalo representava seu pai. Assim, a fobia de cavalo expressava um conflito disfarçado, cujo conteúdo inconsciente era o medo do pai (agente castrador da vivência edípica). O pai edípico e o totem, portanto, representam e promulgam a lei de proibição do incesto.

A psicanálise revelou que o animal totêmico é, na realidade, um substituto do pai. Isto entra em acordo com o fato contraditório de que, embora a morte do animal seja em regra proibida, sua matança, no entanto, é uma ocasião festiva. A atitude emocional ambivalente - que até hoje caracteriza o complexo-pai em nossos filhos e com tanta frequência persiste na vida adulta - parece estender-se ao animal totêmico em sua capacidade de substituto do pai (Freud, [1913] 1976). O texto "Totem e tabu" apresenta como condição de possibilidade da instauração da cultura a morte do pai totêmico. Assim, mais uma vez, para que os filhos alcancem o lugar de sujeitos será preciso o assassinato do pai. No entanto, "o pai morto tornou-se mais forte do que o fora vivo" (Freud, [1913] 1976: 171). Freud finaliza esta obra citando Goethe: "Aquilo que herdaste, conquista-o para fazê-lo teu” (Freud, [1913] 1976: 171).

A última versão freudiana sobre o pai aparece em "Moisés e o monoteísmo". No livro, [Moisés] coloca como centro da discussão a origem do povo judeu. Freud anuncia um não-judeu como pai do judaísmo. Fazer do profeta do judaísmo, Moisés, um estrangeiro, um egípcio está em perfeita consonância com o princípio do judaísmo. Ou seja, o princípio da estrangeiridade, da diferença, daquilo que escapa. É interessante notar que Freud, em "Estudos autobiográficos" ([1925a] 1976), ressalta a condição de errância de sua família, acentuando a prevalência da estrangeiridade sobre a identidade na sua história pessoal. 
Reafirmando a situação de estrangeiridade, podemos falar sobre a transcendência absoluta de $\mathrm{YHVH}$, anunciando a presença que se define por uma ausência. $\mathrm{O}$ tetragrama é impronunciável e, portanto, escapa à representação, colocando como ponto de partida para o ethos judaico a questão da alteridade radical.

Fuks (2000) busca, na leitura de Lévinas sobre o deus judaico, elementos para compreender a dimensão de alteridade constitutiva do povo judeu. Reproduzimos, pois, as passagens do texto de Fuks que se dedicam à leitura do termo Kadosh. Segundo a autora, a leitura de Lévinas sobre o termo hebraico aplicado a deus, Kadosh, se traduz por santo. Etimologicamente, santo significa "separado"; "a inscrição de nome de Deus seria a inscrição originária da diferença". Kadosh designa a alteridade radicalmente separada e dessacralizada, isto é, sem conteúdo, sem objeto e sem forma aderida, transcendente até a Ausência. E, porque habita fora do espaço e mais longe que o tempo, o santo será sempre o Estrangeiro dos estrangeiros. Portanto, a estranheza do Deus judaico é, absolutamente, conforme à estranheza de seu povo (Fuks, 2000).

Além disso, Moisés, segundo Freud, transmitiu aos judeus um enorme orgulho por serem um povo escolhido. A proibição de adorarem imagens também teria contribuído para o avanço em intelectualidade, apregoado por Freud. Assim, o povo judeu reteve uma inclinação para os interesses intelectuais e, mais precisamente, para a literatura. Esse dado é importante para pensarmos sobre a transmissão, pois o povo judeu transmite a palavra via "Escrituras Sagradas".

Kupfer (2004) relembra que, no prefácio da edição de suas "Obras em hebraico", escrito em 1930, Freud coloca uma questão sobre seu judaísmo. Ele se pergunta como é possível que, mesmo tendo abandonado todos os traços comuns aos judeus, ainda tenha lhe restado provavelmente sua essência. "Evidentemente, a questão subjacente era uma questão sobre o que poderia ter restado, em permanência, daquilo que seu pai judeu lhe havia transmitido" (Kupfer, 2004: 82).

No texto sobre Moisés, Freud demonstra que um homem só é pai na medida em que se reconhece como filho (Marcos, 2003: 31). Moisés é descrito como um pai autoritário, o que acaba por provocar revoltas de seu povo. Revoltas estas suprimidas mediante sangrentos castigos (Freud, [1939] 1976). A tese freudiana é de que Moisés tenha sido morto pelos judeus, uma analogia ao pai que acaba sendo vítima do filho.

O recalque recai sobre este ato, mas o sentimento de culpa daí advindo acaba por propiciar o surgimento de uma nova religião, a católica. O sentimento de culpa passa a ser nomeado como pecado original. É necessário, então, que o Filho assuma a culpa de todos os pecados da humanidade, permitindo a própria morte e, assim, expiando o pecado original. "O redentor não podia ser outro senão a pessoa 
mais culpada, o cabeça da reunião de irmãos que havia derrotado o pai” (Freud, [1939] 1976:107). De acordo com Freud, se o judaísmo foi uma religião do pai, o cristianismo é a religião do filho. Momento este em que o filho, efetivamente, toma o lugar do pai.

A consequência da consolidação do pensamento judaico-cristão é que a paternidade fica referida e encarnada numa pessoa. De acordo com Felix (1998), o indivíduo nas sociedades tribais não pertencia aos pais, mas ao grupo. Com o advento do cristianismo, a paternidade fica de vez vinculada a uma pessoa particular.

A partir destas considerações, percebemos que o pai necessita ser construído pelo filho, mas para que o filho possa ser pai é necessário destruí-lo. Assim, pergunta Borges: "Como um pai se sustenta, assume, deseja estar na posição de pai, se o filho pode ser uma ameaça?" (Borges, 2006: 21). Para responder a esta questão, retomemos os três mitos freudianos do pai. Vimos que, para Freud, o pai é o pai morto, ou, mais que isso, o pai é o pai morto pelo filho. Mas não seria exatamente o caráter mortificado deste pai a garantia de sua fortaleza? Dito de outro modo, o pai morto se eterniza no filho, na medida em que, através da identificação, surge o supereu, herdeiro do complexo de Édipo.

O percurso que Freud percorre para falar sobre o pai é instigante. Ele parte do mito de Édipo - cuja trajetória se inicia antes mesmo de este nascer (as marcas do Outro) -, passa pelo pai da horda - tirânico, castrador, que os filhos têm que derrotar -, chegando, finalmente, ao pai que somente se reconhece como tal a partir do reconhecimento enquanto filho.

Esta trajetória é, em certa forma, similar àquela que o menino deve realizar para ser pai. É necessário lidar, num primeiro momento, com aquilo que já estava presente mesmo antes do nascimento. Depois, é preciso se haver com o pai. $\mathrm{O}$ que foi herdado necessita ser conquistado efetivamente para que o menino possa considerá-lo seu. Reconhecendo-se como filho, o menino pode, finalmente, ser pai. Esta passagem, no entanto, implica o reencontro com a castração.

Assim, a dissolução do Édipo nos meninos é ocasionada pelo temor da castração, pelo interesse narcísico nos órgãos genitais. Nas meninas é o complexo de castração que inicia o Édipo. Para o menino, o efeito do complexo de castração é a identificação com o objeto paterno.

Nossa hipótese, no entanto, é que não podemos supor uma resolução definitiva do complexo, pois é justamente a relação do sujeito com a castração que determina sua posição no mundo em termos de estrutura. Dissolução, declínio, naufrágio... seja qual for o termo, algo resta. $\mathrm{O}$ encontro do sujeito com a paternidade não é sem efeitos. Ser pai implica uma queda narcísica por um lado, mas um ganho, também narcísico, por outro. 
A queda narcísica está relacionada ao fim das certezas que o encontro com a castração provoca. Muitos homens não suportam este lugar. É o momento propício para a irrupção da psicose em alguns casos. Hoje, verificamos também o grande aumento de famílias "sem pai", ou seja, mulheres que sozinhas criam os filhos. Seria uma opção destas mulheres? Ou, pelo contrário, uma constatação de que os antigos companheiros, pais de seus filhos, não suportaram tal compromisso?

Assim, de acordo com Borges (2006), é fundamental que o homem suporte o ódio que vem do filho, pois estes sentimentos ambivalentes são revividos por ele enquanto pai. Se a função paterna pode ser transmitida, é porque se estabelece uma relação dialética em que o pai faz o filho e o filho faz o pai. Para Kupfer (2004), transmitir é transmitir a linguagem enquanto estrutura:

Poderíamos dizer ainda que o Pai transmite um sistema simbólico que assinala os lugares de identificação e de diferenças, de continuidade e de cortes. Um sistema que produz a ilusão da imortalidade, mas que torna presente ao mesmo tempo o fim e a morte na medida em que esse sistema marca o sujeito enquanto castrado e na medida em que pai e mãe renunciam a fazer de seu filho uma simples extensão do plasma germinal de que fala Freud (Kupfer, 2004: 85).

Uma das imagens a que Freud recorre para demonstrar o pavor da castração é a cabeça de Medusa. Segundo a lenda, Medusa era uma linda jovem que se orgulhava da beleza de seus cabelos, mas se atreveu a competir com Minerva. A Deusa, então, privou-a de seus encantos e transformou seus cabelos em serpentes. Todos que se arriscavam a fitá-la nos olhos eram transformados em pedra. Perseu, no entanto, conseguiu cortar a cabeça de Medusa, guiando-se pela imagem de seu rosto refletido em seu brilhante escudo.

Encarar a castração, tal qual Perseu frente a Medusa, demonstra que nem todos os homens viram pedras diante da paternidade, e que é possível se eternizar em outro ser humano, transmitindo, para além dos genes, o simbólico.

\section{REFERÊNCIAS}

Amazonas, M. C. L. A \& Braga, M. G. R. (2004). Uma redescrição de família e a função paterna. Encontro. UNIA, 9(10), 33-46.

Borges, A. A. P. (2006). O desejo de ser pai: algumas vicissitudes da função paterna. (Dissertação de Mestrado. Puc-Minas, Belo Horizonte. MG). Disponível em: <http://www. sistemas.pucminas.br/BDP/SilverStream/Pages/pg_BDPPrincipal.html>. 
Calligaris, C. (1996.). Hello Brasil! Notas de um psicanalista europeu viajando ao Brasil. São Paulo: Escuta.

Felix, R. O. (1998). A morte como mestre. (Dissertação de Mestrado. Curso de Pós-Graduação em Teoria Psicanalítica). Universidade Federal do Rio de Janeiro, Rio de Janeiro.

Freud, S. ([1912-1913] 1913/1976). Totem e tabu. Obras completas, ESB, v. XIII. Rio de Janeiro: Imago.

Freud, S. (1923/1976). A organização genital infantil: uma interpolação na teoria da sexualidade. Obras completas, ESB, v. XIX. Rio de Janeiro: Imago.

Freud, S. (1924/1976). A dissolução do complexo de Édipo. Obras completas, ESB, v. XXI. Rio de Janeiro: Imago.

Freud, S. (1925a/1976). Um estudo autobiográfico. Obras completas, ESB, v. XX. Rio de Janeiro: Imago.

Freud, S. (1925b/1976). Algumas consequências psíquicas da distinção anatômica entre os sexos. Obras completas, ESB, v. XIX. Rio de Janeiro: Imago.

Freud, S. (1931/1976). Sexualidade feminina. Obras completas, ESB, v. XXI. Rio de Janeiro: Imago.

Freud, S. ([1932] 1933/1976). Feminilidade - conf. XXXIII. Obras completas, ESB, v. XXII. Rio de Janeiro: Imago.

Freud, S. ([1934-1938] 1939/1976). Moisés e o monoteísmo: três ensaios. Obras completas, $E S B$, v. XXIII. Rio de Janeiro: Imago.

Freud, S. ([1892-1899] 1950/1976). Extratos dos documentos dirigidos a Fliess. Obras completas, ESB, v. III. Rio de Janeiro: Imago.

Fuks, B. B. (2000). Freud e a judeidade. A vocação do exílio. Rio de Janeiro: Jorge Zahar.

Kupfer, M. C. M. (2004). A transmissão do pai e suas consequências para a psicanálise de crianças. In: Bernardino, L. M. F. (Org.). Psicanalisar crianças: que desejo é esse? Salvador: Ágalma.

Laplanche, J. (1988). Problemáticas II. Castração. Simbolizações. (Tradução de Álvaro Cabral). São Paulo: Martins Fontes.

Marcos, C. M. (2003). As versōes freudianas do pai. Psicologia em Revista, 10(14), 2534.

Moreira, J. O. (2004). Édipo em Freud: o movimento de uma teoria. Psicol. estud., 9(2), 219-227, Maringá.

Rocha, Z. (2002). Feminilidade e castração: seus impasses no discurso freudiano sobre a sexualidade feminina. Revista Latinoamericana Psicopatologia Fundamental, 1, 128-151.

Recebido em 05 de novembro de 2008 Aceito para publicação em 10 de novembro de 2010 